
УДК 615.014.073:547.972.3:615.322
A. SAVYCH (http://orcid.org/0000-0001-6053-7625),
L. KRYSKIW (https://orcid.org/0000-0001-5129-8167),
L. MOSULA (https://orcid.org/0000-0003-3339-0562)
Horbachevsky Ternopil National Medical University

\section{DETERMINATION OF THE TOTAL CONTENT OF FLAVONOIDS IN HERBAL MIXTURES WITH ANTI-DIABETIC ACTIVITY}

Key words: herbal mixtures, flavonoids, UV-spectrophotometry, diabetes mellitus, phytotherapy, antioxidant activity, rutin

А. О. САВИЧ (http://orcid.org/0000-0001-6053-7625), канд. фарм. наук, доцент,

Л. С. КРИСЬКІВ (https://orcid.org/0000-0001-5129-8167), канд. фарм. наук,

Л. М. МОСУЛА (https://orcid.org/0000-0003-3339-0562), канд. фарм. наук, доцент

Тернопільський національний медичний університет імені І. Я. Горбачевького МОЗ України

ВИЗНАЧЕННЯ ЗАГАЛЬНОГО ВМІСТУ ФЛАВОНОЇДІВ У РОСЛИННИХ ЗБОРАХ ІЗ ПРОТИДІАБЕТИЧНОЮ АКТИВНІСТЮ

Ключові слова: рослинні збори, флавоноїди, УФ-спектрофотометрія, цукровий діабет, фітотерапія, антиоксидантна активність, рутин

Diabetes mellitus is characterized by a rapid increase in the rate of spread and severe complications e.g. angiopathy, which significantly impairs the prognosis and life quality of patients, so it belongs to the global health problems. [1,2]. As of 2019, official International Diabetes Federation data report an increase in the number of patients to 642 million by 2040 [3]. An important problem of pharmacovigilance is that existing pharmacotherapy is able to reduce hyperglycemia, but it is not always possible to stabilize fluctuations of glycemia values during the day and keep it at optimal level $[4,5]$. This leads to the formation of a cascade of pathological processes - excessive glycation and inactivation of the body's antioxidant defense system, triggering free radical oxidation of lipids and, consequently, the development of oxidative stress, which leads to the development and progression of diabetic complications [6,7]. In turn, oxidative stress, which is the result of the accumulation of reactive oxygen species (ROS: hydroperoxyl, superoxide, hydrogen peroxide and hydroxyl radicals), nitrogen molecules (RNS: peroxynitrite of active nitrogen) and some derivatives of heavy metals (iron and copper) is the main event for the development of insulin resistance $[8,9]$. This may reduce peripheral insulin sensitivity through major molecular mechanisms such as $\beta$-cell dysfunction, inflammatory responses, decreased regulation and / or localization of glucose transporter 4 (GLUT-4), mitochondrial dysfunction, and abnormal insulin signaling pathways [10,11]. Hereat, one of the main priorities of the medical field is pharmacotherapy improvement and development of antidiabetic drugs with antioxidant properties for the treatment and prevention of this pathology [12].

Phytotherapy is among such promising areas, as compared with the use of traditional oral drugs, it has a number of significant advantages, including a safe pharmacological profile, mild therapeutic effect, low risk of side effects with long-term use, the possibility of combining with traditional therapies, due to the presence of complex of biologically active compounds it has a multifaceted effect. $[13,14]$. Since herbal mixtures are likely to contain a wide range of biologically active compounds, it is possible to cover more links in the pathogenetic mechanism of diabetes and prevent its complications [15, $16]$, so the combination of medicinal plants is worth the attention of researchers [17, 18]. Plant biocompounds have a wide range of pharmacological action and a variety of mechanisms of influencing on the development of diabetes (pathogenesis of which 
involves the development of insulin resistance, relative insulin deficiency, which leads to the decrease of secretory activity of $\beta$-cells of the pancreatic gland) and diabetic angiopathies (inactivation of antioxidant protection system, activation of lipid peroxidation and development of oxidative stress)

The pathogenesis of diabetes includes insulin resistance and, due to relative insulin deficiency, a decrease in the secretory function of pancreatic $\beta$-cells and a decrease in the protective activity of the antioxidant system, promotion of lipid peroxidation and oxidative stress, while plant biologically active compounds have different mechanisms of pharmacological correction of these metabolic abnormalities [19, 20].

In this regard, the important biologically active substances are hydroxylated polyphenolic compounds, namely flavonoids. The chemical structure of flavonoids is based on fifteen-carbon skeleton consisting of two benzene rings linked via a heterocyclic pyran ring [21]. The pharmacological activities of this biocompounds depend on their structural class, degree of hydroxylation, other substitutions and conjugations, and degree of polymerization [22]. In particular, functional hydroxyl groups in flavonoids mediate their antioxidant effects by scavenging free radicals and/ or by chelating metal ions $[23,24]$.

Antioxidant activity of flavonoids in the treatment and prevention of diabetes and its complications is important because they can include suppression of ROS formation either by inhibition of enzymes or by chelating trace elements involved in free radical generation $[25,26]$; scavenging ROS; inhibition the enzymes involved in ROS generation - microsomal monooxygenase, glutathione S-transferase, mitochondrial succinoxidase, nicotinamide adenine dinucleotide phosphate (NADP) oxidase, and so forth $[27,28]$.

Therefore, the aim of study was to determine the total flavonoid content in some herbal mixtures with previously studied antidiabetic activity in vivo [29].

\section{M a terials and methods}

Plant materials: For the study took plant raw materials collected in June-August 2020 in the Ternopil and Carpathian region, Ukraine (Vaccinium myrtillus leaf). The harvested raw materials were dried, homogenized and stored according to GACP guidelines [30]. Identification of plant raw materials was carried out at the Department of Pharmacognosy with Medical Botany of I. Horbachevsky Ternopil National Medical University, Ternopil, Ukraine. Samples of harvested raw materials were transferred to the Departmental herbarium for further processing

Five different herbal mixtures with proven in preliminary in vivo antidiabetic activity tests [29] were choosed for investigation. The compositions of this mixtures were as shown in the table.

Chemicals and standards: Chemical reference substance (CRS) of rutin was of primary reference standard grade ( $\geq 95 \%$ purity HPLC) and was purchased from Sigma-Aldrich Chemical Company (Germany). Absolute ethanol, aluminium chloride and acetic acid was purchased from Sfera Sim LTD (Ukraine). Water used in the studies was produced by MilliQ Gradient water deionizaton system (USA).

Instrumentation and conditions: spectrophotometric measurements were performed on spectrophotometer UV-1800 Shimadzu (Japan) equipped with $1 \mathrm{~cm}$ matched quartz cells. Determination of the total flavonoid content was performed at a maximum absorption of $415 \mathrm{~nm}$ after complexation with aluminum chloride $\left(\mathrm{AlCl}_{3}\right)$. The measurements were performed 40 min after the addition of $\mathrm{AlCl}_{3}$ [31]. 
Compositions of the herbal mixtures

\begin{tabular}{|c|c|c|c|}
\hline Herbal mixtures & Herbal drug component & Portion in the mixture, $\%$ & Relative ratio \\
\hline No 3 & $\begin{array}{l}\text { Urtica dioica leaf } \\
\text { Cichorium intybus roots } \\
\text { Rosa majalis fruits } \\
\text { Elymus repens rhizome } \\
\text { Taraxacum officinale roots }\end{array}$ & $\begin{array}{l}26.32 \\
26.32 \\
21.05 \\
15.79 \\
10.52\end{array}$ & $\begin{array}{l}5 \\
5 \\
4 \\
3 \\
2\end{array}$ \\
\hline No 4 & $\begin{array}{l}\text { Arctium lappa roots } \\
\text { Elymus repens rhizome } \\
\text { Zea mays columns with stigmas } \\
\text { Helichrysum arenarium flowers } \\
\text { Rosa majalis fruits }\end{array}$ & $\begin{array}{l}26.32 \\
26.32 \\
21.05 \\
15.79 \\
10.52\end{array}$ & $\begin{array}{l}5 \\
5 \\
4 \\
3 \\
2\end{array}$ \\
\hline No 7 & $\begin{array}{l}\text { Inula helenium rhizome with roots } \\
\text { Helichrysi arenarium flowers } \\
\text { Zea mays columns with stigmas } \\
\text { Origanum vulgari herb } \\
\text { Rosa majalis fruits } \\
\text { Taraxacum officinale roots }\end{array}$ & $\begin{array}{l}10.0 \\
20.0 \\
20.0 \\
20.0 \\
20.0 \\
10.0\end{array}$ & $\begin{array}{l}1 \\
2 \\
2 \\
2 \\
2 \\
1\end{array}$ \\
\hline No 13 & $\begin{array}{l}\text { Cichorium intybus roots } \\
\text { Elymus repens rhizome } \\
\text { Helichrysum arenarium flowers } \\
\text { Rosa majalis fruits } \\
\text { Zea mays columns with stigmas }\end{array}$ & $\begin{array}{l}26.32 \\
26.32 \\
21.05 \\
15.79 \\
10.52 \\
\end{array}$ & $\begin{array}{l}5 \\
5 \\
4 \\
3 \\
2\end{array}$ \\
\hline No 19 & $\begin{array}{l}\text { Urtica dioica leaf } \\
\text { Taraxacum officinale roots } \\
\text { Vaccinium myrtillus leaf } \\
\text { Rosa majalis fruits } \\
\text { Mentha piperita herb }\end{array}$ & $\begin{array}{l}20.0 \\
20.0 \\
20.0 \\
20.0 \\
20.0\end{array}$ & $\begin{array}{l}1 \\
1 \\
1 \\
1 \\
1\end{array}$ \\
\hline
\end{tabular}

Exrtact: $1.00 \mathrm{~g}$ (accurate weight) of each powdered herbal raw materials was placed into a $150 \mathrm{~mL}$ flask. Then was added $30 \mathrm{~mL}$ of ethanol $50 \%(\mathrm{v} / \mathrm{v})$ and was heated on a water bath under reflux for 30 minutes. The hot extract was filtered through cotton wool to a volumetric flask of $100 \mathrm{~mL}$. The cotton wool and raw materials residue were returned to the flask and a new extractive cycle was performed by 15 min with $30 \mathrm{~mL}$ of ethanol $50 \%(\mathrm{v} / \mathrm{v})$. This procedure was repeated two times. The filtrates were collected in the $100 \mathrm{~mL}$ volumetric flask, and the volume completed to the mark with ethanol $50 \%(\mathrm{v} / \mathrm{v})$.

Stock solution: the solution resulting from the reflux was taken as stock solution.

Test solution: $1 \mathrm{~mL}$ of stock solution was placed into $25 \mathrm{~mL}$ volumetric flask and $2 \mathrm{~mL}$ of $3 \% \mathrm{AlCl}_{3}$ in $95 \%$ ethanol (w/v) solution was added. Then volume was completed to the mark with $95 \%$ ethanol.

Reference solution: $1 \mathrm{~mL}$ of stock solution was placed into $25 \mathrm{~mL}$ volumetric flask, then 1 drop of dilute acetic acid solution was added and volume was completed to the mark with $95 \%$ ethanol.

Standard solution: $0.05 \mathrm{~g}$ (accurate weight) of CRS of rutin was dissolved in $100 \mathrm{~mL}$ of $95 \%$ ethanol in a water bath. Then $1 \mathrm{~mL}$ of rutin solution was transferred in a $25 \mathrm{~mL}$ volumetric flask, 1 drop of dilute acetic acid solution was added to it and was completed to the mark with $95 \%$ ethanol.

The obtained results were processed according to the recommendations of the European Pharmacopoeia [32] using the methods of mathematical statistics of the MS Excel statistical package. 
Results and discussion

The results of spectrophotometric determination of the total flavonoid content in terms of rutin are presented in figs. 1-2.

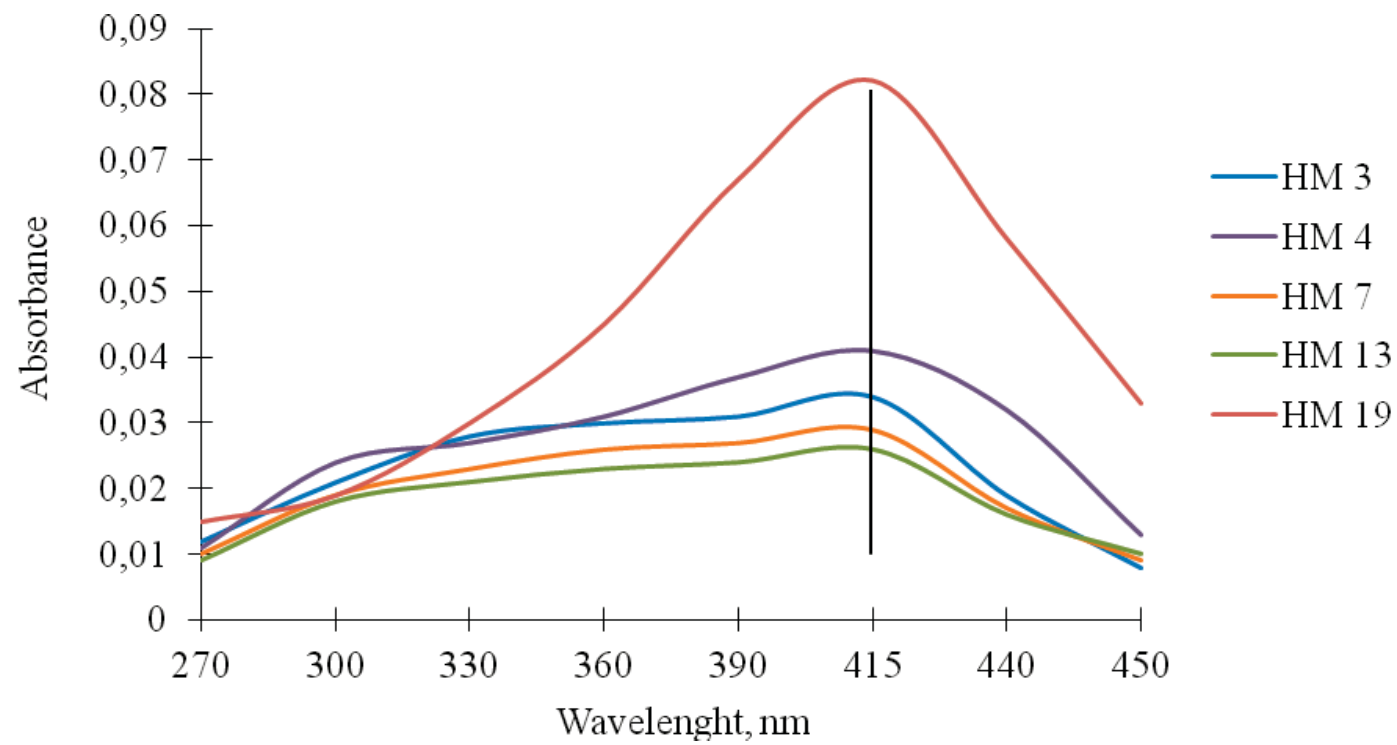

Fig. 1. Absorption spectra of $\mathrm{AlCl}_{3}$-flavonoid complexes for examined herbal mixtures (HM - herbal mixture)

The method of determination was based on the reaction of complexation of flavonoids with $\mathrm{AlCl}_{3}$. The maximum absorption of all samples was at $\lambda_{\max }=415 \pm 0.5 \mathrm{~nm}$.

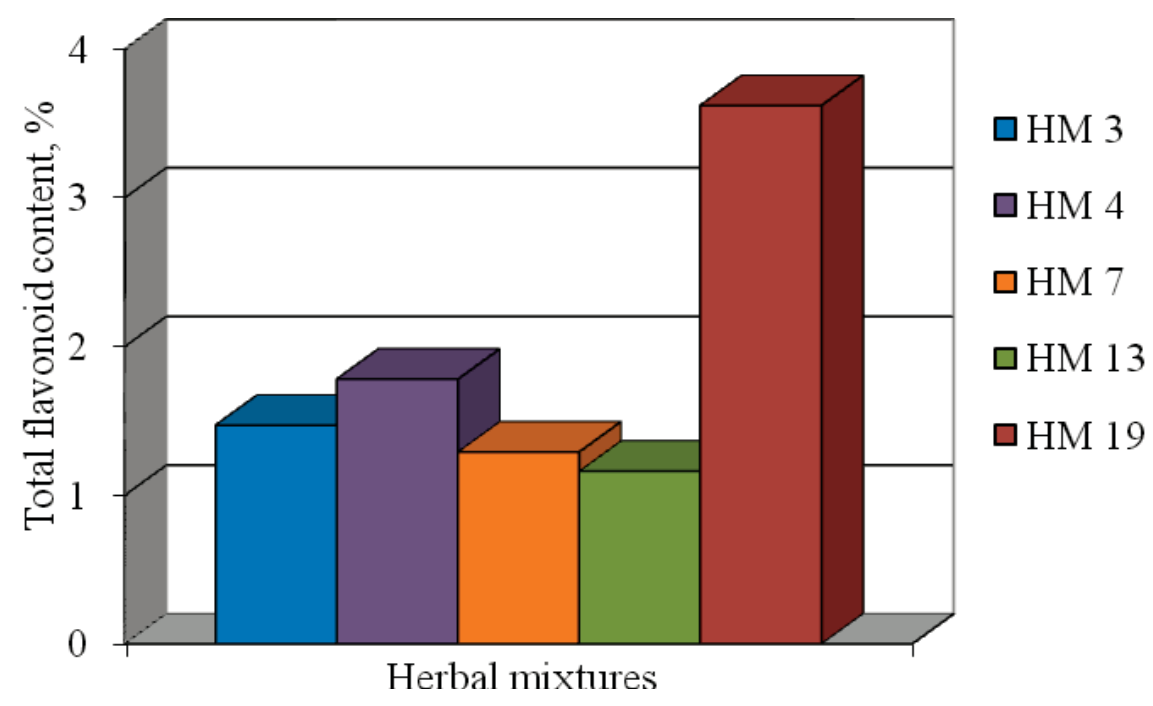

Fig. 2. Total flavonoid content in the herbal mixtures determined spectrophotometrically

(Values are expressed as mean $\pm \mathrm{SD}(n=4, P=0,95 ; \mathrm{HM}$ - herbal mixture) $)$

According to UV-spectrophotometric determination, it was found that the total flavonoid content was $1.47 \pm 0.04 \%$ in the herbal mixture No. $3,1.78 \pm 0.04 \%$ in the herbal mixture No. $4,1.29 \pm 0.02 \%$ in the herbal mixture No. $7,1.16 \pm 0.02 \%$ in the herbal mixture No. 13 and $3.62 \pm 0.06 \%$ in the herbal mixture No. 19 (fig. 2). 
Thus, the sufficient content of flavonoids in the studied herbal mixtures (fig. 2) may indicate the ability of these mixtures to prevent the development of oxidative stress, which is the main pathogenic mechanism of diabetic angiopathies [12].

The obtained data testify to the expediency of using the studied herbal mixtures in order to optimize antidiabetic pharmacotherapy.

\section{Con c l u s i on s}

1. The results of UV-spectrophotometric analysis indicate the high content of flavonoids in the studied herbal mixtures that provides the powerful antioxidant activity, which is an important factor in the treatment of diabetes and in preventing the development of diabetic angiopathies. The best result on the total flavonoid content $(3.62 \pm 0.06 \%)$ was in the herbal mixture No. 19, which contains Urtica dioica L. leaf, Taraxacum officinale L. roots, Vaccinium myrtillus L. leaf, Rosa majalis L. fruits, Mentha piperita L. herb.

2. Conducted phytochemical studies may indicate a correlation between the content of flavonoids and pharmacological properties of the studied mixtures, because the functional hydroxyl groups of the latter possess strong antioxidant activity by neutralizing free radicals, chelation of heavy metal ions, increasing the activity of the body's antioxidant defense system and neutralization of lipid peroxidation products, which was confirmed in previous in vivo and in vitro studies.

\section{Conflict of interests. There are no conflicts of interest regarding this study.}

\section{Re f e r e n c e s}

1. Beckman J., Creager M. Vascular Complications of Diabetes // Circ. Res. - 2016. - V. 118, N 11. P. 1771-1785. https://doi.org/10.1161/CIRCRESAHA.115.306884

2. Sarwar N., Gao P., Seshasai K. et al. Diabetes mellitus, fasting blood glucose concentration, and risk of vascular disease: a collaborative meta-analysis of 102 prospective studies // Lancet. - 2010. - V. 376, N 9745. - P. 2215-2222. https://doi.org/10.1016/S0140-6736(10)60484-9

3. Saeedi P., Petersohn I., Salpea P. et al. Global and regional diabetes prevalence estimates for 2019 and projections for 2030 and 2045: Results from the International Diabetes Federation Diabetes Atlas, 9th edition // Diabetes Res. Clin. Pract. - 2019. - V. 157. - 10 p. https://doi.org/10.1016/j.diabres.2019.107843

4. Skyler J. S., Bakris G. L., Bonifacio E. et al. Differentiation of diabetes by pathophysiology, natural history, and prognosis // Diabetes. - 2017. - V. 66, N 2. - P. 241-255. https://doi.org/10.2337/db16-0806

5. Brosch S., De Ferran A. M., Newbould V. et al. Establishing a framework for the use of social media in pharmacovigilance in Europe // Drug Safety. - 2019. - V. 42, N 8. - P. 921-930. https://doi.org/10.1007/ s40264-019-00811-8

6. García-Sánchez A., Miranda-Díaz A. G., Cardona-Muñoz E. G. The role of oxidative stress in physiopathology and pharmacological treatment with pro- and antioxidant properties in chronic diseases // Oxid. Med. Cell. Longev. - 2020. - V. 2020. - 16 p. https://doi.org/10.1155/2020/2082145

7. Yaribeygi H., Sathyapalan T., Atkin S. L. et al. Molecular mechanisms linking oxidative stress and diabetes mellitus // Oxid. Med. Cell. Longev. - 2020. - V. 2020. - 13 p. https://doi.org/10.1155/2020/8609213

8. Oguntibeju O. O. Type 2 diabetes mellitus, oxidative stress and inflammation: examining the links // Int. J. Physiol. Pathophysiol. Pharmacol. - 2019. - V. 11, N 3. - P. 45-63.

9. Gerber P. A., Rutter G. A. The role of oxidative stress and hypoxia in pancreatic beta-cell dysfunction in diabetes mellitus // Antioxid. Redox Signal. - 2017. -V. 26, N 10. - P. 501-518. https://doi.org/10.1089/ ars.2016.6755

10. Tangvarasittichai $S$. Oxidative stress, insulin resistance, dyslipidemia and type 2 diabetes mellitus // World J. Diabetes. - 2015. - V. 6, N 3. - P. 456-480. https://doi.org/10.4239/wjd.v6.i3.456

11. Hajiaghaalipour F., Khalilpourfarshbafi M., Arya A. Modulation of glucose transporter protein by dietary flavonoids in type 2 diabetes mellitus // Int. J. Biol. Sci. - 2015. - V. 11, N 5. - P. 508-524. https://doi. org/10.7150/ijbs.11241

12. Enogieru A. B., Haylett W., Hiss D. C. et al. Rutin as a potent antioxidant: implications for neurodegenerative disorders // Oxid. Med. Cell. Longev. - 2018. - V. 2018. - 17 p. https://doi. org/10.1155/2018/6241017

13. Governa P., Baini G., Borgonetti V. et al. Phytotherapy in the management of diabetes: a review // Molecules. - 2018. - V. 23, N 1. - P. 105. https://doi.org/10.3390/molecules23010105

14. Kooti W., Farokhipour M., Asadzadeh Z. et al. The role of medicinal plants in the treatment of diabetes: a systematic review // Electron. Physician. - 2016. - V. 8, N 1. - P. 1832-1842. https://doi.org/10.19082/1832 
15. El-Abhar H., Schaalan M. Phytotherapy in diabetes: Review on potential mechanistic perspectives // World J. Diabetes. - 2014. - V. 5, N 2. - P. 176-197. http://dx.doi.org/10.4239/wjd.v5.i2.176

16. Deepa J., Aleykutty N., Harindran J. Effect of combination of two plant extracts on diabetes mellitus // Int. J. Pharmacy Pharm. Sci. - 2018. - V. 10, N 4. - P. 49-52. https://doi.org/10.22159/ijpps.2018v10i4.24100

17. Öztürk Y., Öztürk N. Plant- and nutraceutical-based approach for the management of diabetes and its neurological complications: a narrative review // Curr. Pharm. Des. - 2019. - V. 25, N 33. - P. 3536-3549. https://doi.org/10.2174/1381612825666191014165633

18. Wright N., Wilson L., Smith M. et al. The BROAD study: A randomised controlled trial using a whole food plant-based diet in the community for obesity, ischaemic heart disease or diabetes // Nutr. Diabetes. 2017. - V. 20, N 7. - 10 p. https://doi.org/10.1038/nutd.2017.3

19. Kinichenko A. O., Klevanova V. S., Trzhetsynskiy S. D., Maletskiy N. N. Hypoglycemic properties of Portulaca oleracea herb in the experimental conditions of dexamethasone diabetes mellitus in rats // Farmats. zhurn. - 2018. - № 2. - P. 62-68. https://doi.org/10.32352/0367-3057.2.17.08

20. Ilkhanizadeh B., Shirpoor A., Ansari K. et. al. Protective effects of Ginger (Zingiber officinale) extract against diabetes-induced heart abnormality in rats // Diabetes Metab. J. - 2016. - V. 40, N 1. - P. 46-53 https://doi.org/10.4093/dmj.2016.40.1.46

21. Alkhalidy H., Wang Y., Liu D. Dietary Flavonoids in the Prevention of T2D: An Overview // Nutrients - 2018. - V. 10, N 4. - 438 p. https://doi.org/10.3390/nu10040438

22. Kumar S., Pandey A. K. Chemistry and biological activities of flavonoids: an overview // The Sci. World J. - 2013. - V. 2013. - 16 p. https://doi.org/10.1155/2013/162750

23. Kawser Hossain M., Abdal Dayem A., Han J. et al. Molecular mechanisms of the anti-obesity and anti-diabetic properties of flavonoids // Inter. J. Mol. Sci. - 2016. - V. 17, N 4. - 569 p. https://doi.org/10.3390/ ijms17040569

24. Nasri H., Shirzad H., Baradaran A. et al. Antioxidant plants and diabetes mellitus // J. Res. Med. Sci. - 2015. - V. 20, N 5. - P. 491-502. https://doi.org/10.4103/1735-1995.163977

25. Sarian M. N., Ahmed Q. U., Mat So'ad S. et al. Antioxidant and antidiabetic effects of flavonoids: a structure-activity relationship based study // BioMed Res. Inter. - 2017. - V. 2017. - 14 p. https://doi. org/10.1155/2017/8386065

26. Хи D., Hи M. J., Wang Y. Q. et al. Antioxidant activities of quercetin and its complexes for medicinal application // Molecules. - 2019. - V. 24, N 6. - 15 p. https://doi.org/10.3390/molecules24061123

27. Zheng Y. Z., Deng G., Guo R. et al. DFT studies on the antioxidant activity of naringenin and its derivatives: effects of the substituents at C3 // Int. J. Mol. Sci. - 2019. - V. 20, N 6. - 13 p. https://doi. org/10.3390/ijms20061450

28. Dabeek W. M., Marra M. V. Dietary quercetin and kaempferol: bioavailability and potential cardiovascular-related bioactivity in humans // Nutrients. - 2019. - V. 11, N 10. - 19 p. https://doi.org/10.3390/ nu11102288

29. Savych A., Marchyshyn M., Basaraba R. Screening study of hypoglycemic activity of the herbal mixtures (Message 1) // ScienceRise: Pharmac. Sci. - 2020. - V. 4, N 26. - P. 40-46. https://doi. org/10.15587/2519-4852.2020.210734

30. WHO Guidelines on good agricultural and mixture practices (GACP) for medicinal plants. - Geneva, Switzerland: World Health Organization, 2003. - 80 p.

31. Da Silva L. A., Pezzini B. R., Soares L. Spectrophotometric determination of the total flavonoid content in Ocimum basilicum L. (Lamiaceae) leaves // Pharmacogn. Mag. - 2015. -V. 11, N 41. - P. 96-101. https://doi.org/10.4103/0973-1296.149721

32. European Pharmacopoeia. Tenth edition. - Strasbourg: Council of Europe EDQM, 2019. - 4730 p.

Надійшла до редакції 29 червня 2021 р. Прийнято до друку 28 серпня 2021 р.

A. Savych (http://orcid.org/0000-0001-6053-7625),

L. Kryskiw (https://orcid.org/0000-0001-5129-8167),

L. Mosula (https://orcid.org/0000-0003-3339-0562)

Horbachevsky Ternopil National Medical University

DETERMINATION OF THE TOTAL CONTENT OF FLAVONOIDS IN HERBAL MIXTURES WITH ANTI-DIABETIC ACTIVITY

Key words: herbal mixtures, flavonoids, UV-spectrophotometry, diabetes mellitus, phytotherapy, antioxidant activity, rutin

A B S T R A C T

Diabetes mellitus is an important social and medical problem, as it causes the development of dangerous complications that lead to disability and mortality. This disease is characterized by a multi-vector pathogenesis that requires a comprehensive approach to treatment. Due to the use of mixtures of medicinal plants in the treatment of diabetes, it is possible to cover all aspects of the development of this disease and its complications, because the combination of different medicinal plants contain more biologically active substances that affect all parts of the pathogenetic mechanism of diabetes mellitus and its complications. Plant biocompounds have a wide range of pharmacological action and various mechanisms of influence on the development of diabetes and diabetic angiopathies (inactivation of the antioxidant defense system, activation of lipid peroxidation and 
the development of oxidative stress). In addition, the niche of the pharmaceutical market of Ukraine with phytomixtures is almost empty.

The aim of the work was to study the total flavonoid content in some herbal mixtures, which have established hypoglycemic, hypolipidemic and antioxidant activity in previous studies in vivo.

The study of the total flavonoid content in herbal samples was carried out by UV-spectrophotometry with the recording of the absorption spectrum of complexation product of flavonoids with aluminum chloride $\left(\lambda_{\max }\right.$ $415 \mathrm{~nm}$ ) in terms of rutin.

According to the results of UV-spectrophotometric determination, it was found that the total flavonoid content in the herbal mixture No 3 was $1.47 \pm 0.04 \%$, in the herbal mixture No $4-1.78 \pm 0.04 \%$, in the herbal mixture No $7-1.29 \pm 0.02 \%$, in the herbal mixture No $13-1.16 \pm 0.02 \%$ and in the herbal mixture No $19-$ $3.62 \pm 0.06 \%$ in terms of rutin.

It was found that the best flavonoid content $(3.62 \pm 0.06 \%)$ was found in the plant mixture No 19 , which contains nettle leaves, dandelion roots, blueberry leaves, rose hips and peppermint herb. Phytochemical studies may indicate a correlation between the content of flavonoids and pharmacological properties of the studied mixtures, because the functional hydroxyl groups of the latter cause strong antioxidant activity by neutralizing free radicals, chelation of heavy metal ions, increasing the activity of antioxidant protection products, which has been confirmed in previous in vivo and in vitro studies.

А. О. Савич (http://orcid.org/0000-0001-6053-7625),

Л. С. Криськів (https://orcid.org/0000-0001-5129-8167),

Л. М. Мосула (https://orcid.org/0000-0003-3339-0562)

Тернопільський начіональний медичний університет імені І. Я. Горбачевького МОЗ Украӥни

ВИЗНАЧЕННЯ ЗАГАЛЬНОГО ВМІСТУ ФЛАВОНОЇДІВ У РОСЛИННИХ ЗБОРАХ ІЗ

ПРОТИДІАБЕТИЧНОЮ АКТИВНІСТЮ

Ключові слова: рослинні збори, флавоноїди, УФ-спектрофотометрія, цукровий діабет, фітотерапія, антиоксидантна активність, рутин

А Н О Т А Ц І Я

Цукровий діабет є важливою соціальною та медичною проблемою, адже спричиняє розвиток небезпечних ускладнень, що призводять до інвалідизації та смертності населення. Це захворювання характеризується багатовекторним патогенезом, що потребує комплексного підходу до лікування. Завдяки застосуванню зборів лікарських рослин у терапії цукрового діабету можна охопити усі ланки розвитку цього захворювання та його ускладнень, оскільки поєднання різних лікарських рослин містять більше біологічно активних речовин, які впливають на всі ланки патогенетичного механізму розвитку цукрового діабету та його ускладнень. Рослинні біосполуки мають широкий спектр фармакологічної дії та різноманітні механізми впливу на розвиток діабету та діабетичних ангіопатій (інактивація системи антиоксидантного захисту, активація перекисного окислення ліпідів та розвиток оксидативного стресу). Окрім цього, ніша фармацевтичного ринку України з фітозборів практично порожня.

Метою роботи було вивчити загальний вміст флавоноїдів у деяких рослинних зборах, що мають встановлену в попередніх дослідженнях in vivo гіпоглікемічну, гіполіпідемічну і антиоксидантну активність.

Дослідження загального вмісту флавоноїдів у рослинних зборах здійснювали методом УФспектрофотометрії з реєстрацією спектра поглинання продукту комплексоутворення флавоноїдів 3 алюміній хлоридом $\left(\lambda_{\max } 415\right.$ нм) у перерахунку на рутин.

За результатами УФ-спектрофотометричного визначення було встановлено, що загальний вміст флавоноїдів у рослинному зборі № 3 становить $1,47 \pm 0,04 \%$, у рослинному зборі № $4-1,78 \pm 0,04 \%$, у рослинному зборі № $7-1,29 \pm 0,02 \%$, у рослинному зборі № $13-1,16 \pm 0,02 \%$ та у рослинному зборі № $19-3,62 \pm 0,06 \%$ у перерахунку на рутин.

Встановлено що за загальним вмістом флавоноїдів найкращий результат $(3,62 \pm 0,06 \%)$ виявився у рослинній суміші № 19, яка містить листя кропиви, корені кульбаби, листя чорниці, плоди шипшини та траву м'яти перцевої. Виконані фітохімічні дослідження можуть свідчити про кореляцію між вмістом флавоноїдів та фармакологічними властивостями досліджуваних сумішей, адже функціональні гідроксильні групи цих біологічно активних речовин зумовлюють потужну антиоксидантну активність шляхом знешкодження вільних радикалів, хелатування іонів важких металів, підвищення активності системи антиоксидантного захисту організму та нейтралізацією продуктів перекисного окиснення ліпідів, що було підтверджено у попередніх дослідженнях in vivo та in vitro. 
А. А. Савич (http://orcid.org/0000-0001-6053-7625),

Л. С. Крыськив (https://orcid.org/0000-0001-5129-8167),

Л. М. Мосула (https://orcid.org/0000-0003-3339-0562)

Тернопольский начиональный медицинский университет им. И. Я. Горбачевского МЗ Украины ОПРЕДЕЛЕНИЕ ОБЩЕГО СОДЕРЖАНИЯ ФЛАВОНОИДОВ В РАСТИТЕЛЬНЫХ СБОРАХ С ПРОТИВОДИАБЕТИЧЕСКОЙ АКТИВНОСТЬЮ

Ключевые слова: растительные сборы, флавоноиды, УФ-спектрофотометрия, сахарный диабет, фитотерапия, антиоксидантная активность, рутин

А Н Н О Т А ЦИЯ

Сахарный диабет является важной социальной и медицинской проблемой, поскольку приводит к развитию опасных осложнений, приводящих к инвалидизации и смертности населения. Это заболевание характеризуется многовекторным патогенезом и требует комплексного подхода к лечению. Благодаря применению сборов лекарственных растений в терапии сахарного диабета можно охватить все звенья развития этого заболевания и его осложнений, поскольку сочетания различных лекарственных растений содержат больше биологически активных веществ, которые влияют на все звенья патогенетического механизма развития сахарного диабета и его осложнений. Растительные биосоединения имеют широкий спектр фармакологического действия и различные механизмы влияния на развитие диабета и диабетических ангиопатий (инактивация системы антиоксидантной защиты, активация перекисного окисления липидов и развитие оксидативного стресса). Кроме этого, ниша фармацевтического рынка Украины по фитосборам практически пуста.

Целью работы было изучение общего содержания флавоноидов в некоторых растительных сборах, которые имеют установленную гипогликемическую, гиполипидемическую и антиоксидантную активность в предыдущих исследованиях in vivo.

Исследование общего содержания флавоноидов в растительных сборах осуществляли методом УФспектрофотометрии с регистрацией спектра поглощения продукта комплексообразования флавоноидов с алюминия хлоридом $\left(\lambda_{\max } 415\right.$ нм) в пересчете на рутин.

По результатам УФ-спектрофотометрического определения было установлено, что общее содержание флавоноидов в растительном сборе № 3 составляет $1,47 \pm 0,04 \%$, в растительном сборе № 4 $1,78 \pm 0,04 \%$, в растительном сборе № $7-1,29 \pm 0,02 \%$, в растительном сборе № $13-1,16 \pm 0,02 \%$ и в растительном сборе № $19-3,62 \pm 0,06 \%$ в пересчете на рутин.

Установлено, что по общему содержанию флавоноидов лучший результат $(3,62 \pm 0,06 \%)$ оказался у растительного сбора № 19, который содержит листья крапивы, корни одуванчика, листья черники, плоды шиповника и траву мяты перечной. Проведенные фитохимические исследования могут свидетельствовать о корреляции между содержанием флавоноидов и фармакологическими свойствами исследуемых смесей, ведь функциональные гидроксильные группы этих биологически активных веществ обусловливают мощную антиоксидантную активность путем обезвреживания свободных радикалов, хелатирования ионов тяжелых металлов, повышения активности антиоксидантной защиты организма и нейтрализацией продуктов перекисного окисления липидов, что было подтверждено в предыдущих исследованиях in vivo и in vitro.

Електронна адреса для листування завторами:lub.s.kryskiw@gmail.com

(Криськів Л. С.) 